\title{
STRUCTURAL AND PHARMACEUTICAL EVALUATION OF 4-HYDROXY-BENZAMIDE DERIVATIVE: ANTI-BACTERIAL AND ANTI-VIRAL POTENT
}

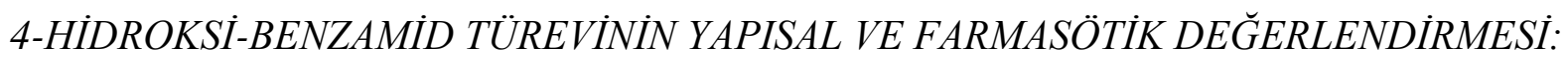 \\ ANTI-BAKTERIYAL VE ANTI-VIRAL ETKI
}

\author{
Aarthi Kundam VASUDEVAN ${ }^{1,2} \mathbb{D}$, Hemamalini RAJAGOPAL ${ }^{1}{ }^{\mathbb{D}}$, \\ Sambanthan MUTHU ${ }^{3,4 *}$ (D) , Fazilath Basha ASIF ${ }^{5}$ (D), Badiadka NARAYANA ${ }^{6}$ (D)
}

${ }^{1}$ Department of Physics, Queen Mary’s College, Chennai, 600 004, Tamil Nadu, India

${ }^{2}$ University of Madras, Chennai, 600 005, Tamil Nadu, India

${ }^{3}$ Department of Physics, Arignar Anna Govt. Arts College, Cheyyar, 604 407, Tamil Nadu, India

${ }^{4}$ Department of Physics, Puratchi Thalaivar Dr. M. G. R. Govt. Arts and Science College, Uthiramerur, 603 406, Tamil Nadu, India

${ }^{5}$ Department of Physics, Islamiah College (Autonomous), Vaniyambadi, 635 752, Tamilnadu, India

${ }^{6}$ Department of Chemistry, Mangalore University, Mangalagangotri, 574 199, Karnataka, India

\section{ABSTRACT}

Objective: In medicinal chemistry, biochemical research and the drug distribution mechanism are crucial. Many common illnesses are caused by bacteria and viruses. The findings of this analysis may be very beneficial to the pharmacy and drug development processes.

Material and Method: Experimental UV-Vis spectroscopy was recorded and compared with the computed results. Reactive sites are analyzed using molecular electrostatic potential and dual descriptor's analysis. Toxicity and druglikeness parameters are explored. Docking study was performed using Autodock tool software.

Result and Discussion: Calculated C11-O19 bond length value is found as 1.226. Calculated band gap energy from molecular orbitals is $4.39 \mathrm{eV}$. Experimentally recorded and computationally predicted UV-VIS spectrum values are comparable with the biomaterial. Binding energy is computed as -6.18 and -5.36 from PL interaction studies. Hydrogen bonds are found between the title ligand and bacterial, viral protein receptors.

\footnotetext{
* Corresponding Author/SorumluYazar: Sambanthan Muthu e-mail / e-posta: mutgee@ gmail.com, Phone / Tel: +919443690138
} 
Keywords: DFT, Drug likeness, MEP, Molecular docking, Toxicity

\section{$\ddot{\mathbf{O Z}}$}

Amaç: Medisinal kimyada biyokimyasal araştırma ve ilaç dağ̆llım mekanizması çok önemlidir. Bakteri ve virüsler pek çok hastalığa neden olmaktadır. Bu çalışmanın bulguları eczacılık ve ilaç geliştirme süreçleri için çok faydalı olabilir.

Gereç ve Yöntem: Kaydedilen deneysel UV-Vis spektrumu hesaplanan sonuçlarla karşılaş̧tırıldı. Reaktif bölgeler, moleküler elektrostatik potansiyeli ve ikili tanımlayıcılar analizi kullanılarak analiz edildi. Toksisite ve ilaç benzerliği parametreleri araştırıldı. Docking çalışması, Autodock programı kullanılarak gerçekleştirildi.

Sonuç ve Tartışma: Hesaplanan C11-O19 bă̆ uzunluğu değeri 1.226 olarak bulundu. Moleküler orbitallerin hesaplanan bant aralı̆ $\breve{l}_{\text {enerjisi }} 4.39 \mathrm{eV}$ 'dir. Deneysel olarak kaydedilen ve hesaplanan tahmini UV-VIS spektrum değerleri, biyomateryal ile karşılaştırllabilir düzeydedir. Bağlanma enerjileri, PL etkileşim çalışmaları ile -6.18 ve -5.36 olarak hesaplandl. Başlık ligand ile bakteriyel ve viral protein reseptörleri arasında hidrojen bağları bulundu.

Anahtar Kelimeler: DFT, İlaç benzerliği, MEP, Moleküler docking, Toksisite

\section{INTRODUCTION}

Amide derivatives are an important class of compounds in different biologically activities [1]. N[(Z)-(4-fluorophenyl)methylideneamino]-4-hydroxybenzamide (FBFBH) is a heterocyclic compound; mostly it is used in medicinal purposes like, antifungal, anticancer, anti-inflammatory, anticonvulsant, antioxidants and antiviral agents [2-5]. Hydroxy-benzamide derivatives have the immense applications in biological field and especially in anti microbial activities [6]. Anti fungal activity of the hydroxybenzamide derivative was explored in earlier studies [7]. Related N-acetyloxy-2-hydroxybenzamide with oxidovanadium (IV) complexes was synthesized and reported for microbial potential studies [6]. Zinc sulfate studies are carried out on N-(2-pyridyl)-2-hydroxybenzamide were reported [8]. Hydroxybenzamide was also reported in solution phase with Iron (III) complexes [9]. The empirical formula for the headline compound is $\mathrm{C}_{14} \mathrm{H}_{11} \mathrm{FN}_{2} \mathrm{O}_{2}$ and molecular weight of the $\mathrm{FBFBH}$ compound is 258.25 .

In this present study, detailed work was done on structural, protein ligand interaction and pharmaceutical properties of anti bacterial and anti viral drug. Density functional theory [10] is impletemented to find the reactive sites of the head line molecule. Chemical properties like electrophilic index, chemical softness is calculated. Electronic properties are calculated from molecular orbitals and compared with experimentally recorded band gap energy using UV-Vis spectroscopy. Toxic parameters were calculated. Protein ligand interaction study is explained.

\section{MATERIAL AND METHOD}

\section{Experimental Details}

The N-[(Z)-(4-fluorophenyl)methylideneamino]-4-hydroxybenzamide compound wass procured from AVRA chemical synthesis. Using DMSO as a solvent, the UV-Vis absorption-spectrum was 
recorded using spectrometer in the range between $200-600 \mathrm{~nm}$. The spectral measurement was recorded at the Sophisticated Analytical Instrumentation Facility (SAIF), IIT, Chennai, India.

\section{Computational Details}

Structural properties were investigated using Gaussian 09W [11]. 6-311++G(d,p) basis was used [1]. Reactive sites are visualized using Gauss view tool. Pharmaceutical properties are calculated using Preadme online tool (https://preadmet.bmdrc.kr/). Protein receptors were screened using PASS online bioactivity server. Choosen proteins are downloaed from RCSB proteins database. Ligand was prepared from optmized structure of the of the headline molecule. Protein ligand interaction study is performed using Autodock 4.2.6. The computation of the atomic charges was done by Kollman and Gasteiger method after the polar hydrogen was attached. The active with the Lamarckian Genetic Algorithm being used to carry site of the proteinwas defined with $126 \AA$ x $126 \AA$ x $126 \AA$ grid size, out the processes. Hbond interactions are visualized using PYMOL graphical interface tool [12].

\section{RESULT AND DISCUSSION}

\section{Optimized Molecular Geometry}

By optimizing the molecule structural properties of any chemical structure can be explored. Experimental crystal structure values of 4-hydroxy-benzamide compound are reported in earlier studies [13]. The computed parameters such as Bond length and bond angle are shown in Table 1. In the title compound there are $14 \mathrm{C}-\mathrm{C}$ bonds, $1 \mathrm{C}=\mathrm{O}$ bond, $1 \mathrm{C}-\mathrm{O}$ bond, $1 \mathrm{C}-\mathrm{F}$ bond, $1 \mathrm{~N}-\mathrm{N}$ bond, $1 \mathrm{C}-\mathrm{N}$ bond and 2 C-N bonds. The calculated bond length of C2-C3, C2-C19, C3-C4, C3-H20, C4-C5, C4-H21, C5-C6, C5-C18, C6-N7, C6-H22, N7-N8, N8-C9, N8-H23, C9-C10, C9-O17 are 1.354, 1.385, 1.390, 1.392, $1.083,1.401,1.085,1.463,1.406,1.280,1.098,1.355,1.391,1.016,1.498$ and 1.214 respectively. Optimized geometrical structure of the headline compound is shown in Figure 1.

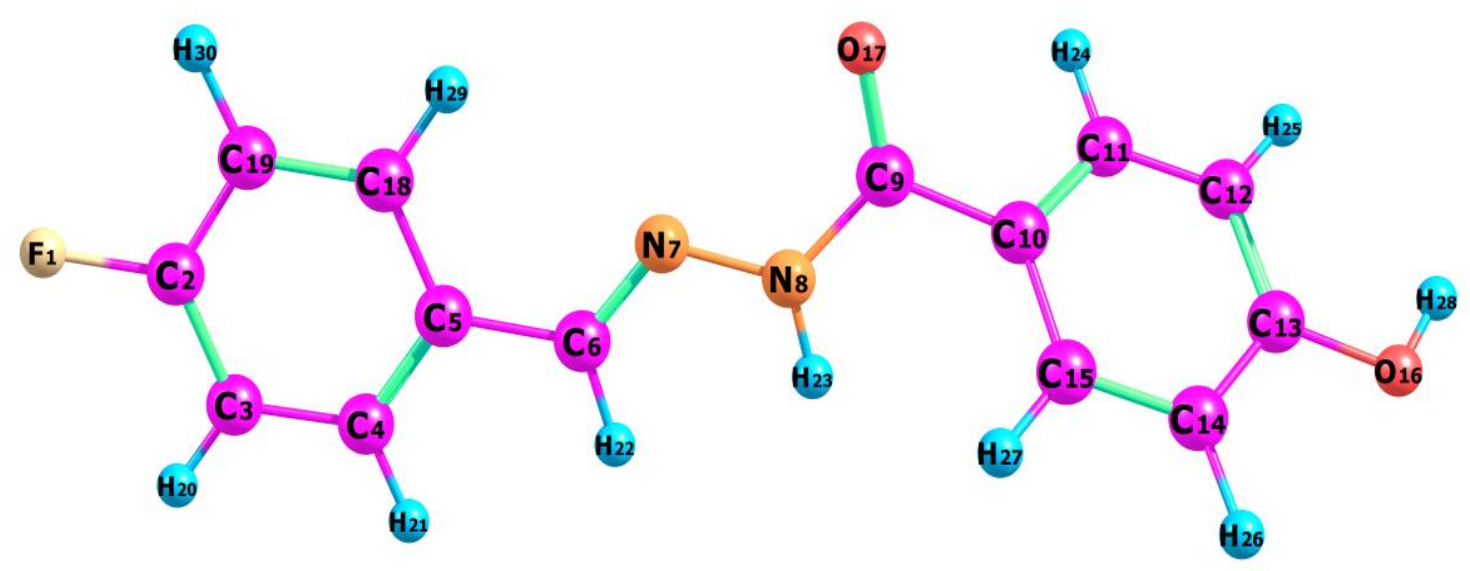

Figure 1. Geometric structure at lowest energy of the title compound 
Table 1. Geometrical parameters of the title compound

\begin{tabular}{|c|c|c|c|c|c|}
\hline Parameters & $\begin{array}{c}\text { B3LYP/ } \\
6-311++G(d, p)\end{array}$ & Parameters & $\begin{array}{c}\text { B3LYP/ } \\
6-311++G(d, p)\end{array}$ & Parameters & $\begin{array}{c}\text { B3LYP/ } \\
6-311++G(d, p)\end{array}$ \\
\hline Bond Length & $(\dot{\mathbf{A}})$ & Bond Angle & $\left({ }^{\circ}\right)$ & Bond Angle & $\left({ }^{\circ}\right)$ \\
\hline $\mathrm{F} 1-\mathrm{C} 2$ & 1.354 & F1-C2-C3 & 118.9 & $\mathrm{C} 10-\mathrm{C} 15-\mathrm{C} 14$ & 121.1 \\
\hline C2-C3 & 1.385 & F1-C2-C19 & 118.8 & C10-C15-H27 & 120.7 \\
\hline C2-C19 & 1.390 & C3-C2-C19 & 122.4 & C12-C11-H24 & 120.5 \\
\hline $\mathrm{C} 3-\mathrm{C} 4$ & 1.392 & $\mathrm{C} 2-\mathrm{C} 3-\mathrm{C} 4$ & 118.3 & C11-C12-C13 & 119.9 \\
\hline C3-H20 & 1.083 & C2-C3-H20 & 119.9 & $\mathrm{C} 11-\mathrm{C} 12-\mathrm{H} 25$ & 120.1 \\
\hline C4-C5 & 1.401 & C2-C19-C18 & 118.8 & $\mathrm{C} 13-\mathrm{C} 12-\mathrm{H} 25$ & 120.0 \\
\hline $\mathrm{C} 4-\mathrm{H} 21$ & 1.085 & C2-C19-H30 & 119.6 & C12-C13-C14 & 120.0 \\
\hline C5-C6 & 1.463 & C4-C3-H20 & 121.8 & C12-C13-O16 & 122.7 \\
\hline C5-C18 & 1.406 & C3-C4-C5 & 121.1 & C14-C13-O16 & 117.3 \\
\hline C6-N7 & 1.280 & C3-C4-H21 & 119.2 & C13-C14-C15 & 119.7 \\
\hline C6-H22 & 1.098 & C5-C4-H21 & 119.7 & C13-C14-H26 & 119.1 \\
\hline N7-N8 & 1.355 & $\mathrm{C} 4-\mathrm{C} 5-\mathrm{C} 6$ & 119.4 & $\mathrm{C} 13-\mathrm{O} 16-\mathrm{H} 28$ & 110.0 \\
\hline N8-C9 & 1.391 & C4-C5-C18 & 118.9 & $\mathrm{C} 15-\mathrm{C} 14-\mathrm{H} 26$ & 121.3 \\
\hline N8-H23 & 1.016 & C6-C5-C18 & 121.7 & $\mathrm{C} 14-\mathrm{C} 15-\mathrm{H} 27$ & 118.2 \\
\hline C9-C10 & 1.498 & C5-C6-N7 & 122.0 & C19-C18-H29 & 120.4 \\
\hline C9-O17 & 1.214 & C5-C6-H22 & 116.6 & C18-C19-H30 & 121.6 \\
\hline C10-C11 & 1.399 & C5-C18-C19 & 120.6 & & \\
\hline $\mathrm{C} 10-\mathrm{C} 15$ & 1.402 & C5-C18-H29 & 119.0 & & \\
\hline C11-C12 & 1.388 & N7-C6-H22 & 121.4 & & \\
\hline $\mathrm{C} 11-\mathrm{H} 24$ & 1.083 & C6-N7-N8 & 117.5 & & \\
\hline C12-C13 & 1.398 & N7-N8-C9 & 121.1 & & \\
\hline $\mathrm{C} 12-\mathrm{H} 25$ & 1.086 & N7-N8-H23 & 119.2 & & \\
\hline C13-C14 & 1.396 & C9-N8-H23 & 119.2 & & \\
\hline C13-O16 & 1.364 & N8-C9-C10 & 114.3 & & \\
\hline C14-C15 & 1.389 & N8-C9-O17 & 122.9 & & \\
\hline C14-H26 & 1.083 & C10-C9-17 & 122.8 & & \\
\hline $\mathrm{C} 15-\mathrm{H} 27$ & 1.084 & C9-C10-C11 & 117.3 & & \\
\hline O16-H28 & 0.963 & C9-C10-C15 & 124.2 & & \\
\hline C18-C19 & 1.387 & C11-C10-C15 & 118.5 & & \\
\hline C18-H29 & 1.083 & $\mathrm{C} 10-\mathrm{C} 11-\mathrm{C} 12$ & 120.9 & & \\
\hline C19-H30 & 1.083 & C10-C11-H24 & 118.5 & & \\
\hline
\end{tabular}

\section{Frontier Molecular Orbitals}

The potential differential among Homo - Lumo, defined as energy band gap, is crucial in deciding a molecule's electrochemical performance and reaction [14].

$$
\text { Chemical potential }(\mu)=\frac{1}{2}\left(\mathrm{E}_{\mathrm{LUMO}}+\mathrm{E}_{\text {Hомо }}\right)
$$

Electronegativity $(\chi)=-\mu=-\frac{1}{2}\left(\mathrm{E}_{\mathrm{LUMO}}+\mathrm{E}_{\mathrm{HOMO}}\right)$

Global hardness $(\eta)=\frac{1}{2}\left(\mathrm{E}_{\mathrm{LUMO}}-\mathrm{E}_{\mathrm{HOMO}}\right)$

Electrophilicity $=\frac{\mu^{2}}{2 \eta}$

$$
\text { Softness }(\mathrm{S})=\frac{1}{\eta}
$$

The computed HOMO-LUMO energies of the FBFBH compound are - $6.3324 \mathrm{eV}$ and -1.9424 $\mathrm{eV}$ respectively and other chemical parameters are shown in Table 2. Band gap Energy value is $4.39 \mathrm{eV}$, 
which is comparable to biologically active material and Electrophilicity index is 3.8993. Excited state surface of headline compound is shown in Figure 2.

The UV-vis spectrum of FBFBH was investigated experimentally with DMSO as a fluid and theoretical [15]. The static or dynamic variables of the chosen molecules in the higher states can be measured reliably using this TD-DFT. Table 3 shows that the wavelength of maximal absorption in theory and experiment is 321 and $261 \mathrm{~nm}$, overall. The highest wavelength value represents the number of electrons injected rings IEFPCM solvation model is implemented to study the solvent effect of head line molecule. The homo-lumo values and UV-Vis band gap values are compactable and which is comparable with bio active material [16]. The comparison spectra of experimental and theoretical data are shown in Figure 3.

Table 2. Important chemical parameters of the title compound

\begin{tabular}{|l|l|}
\hline Parameters & Values \\
\hline HOMO $(\mathrm{eV})$ & -6.3324 \\
\hline LUMO $(\mathrm{eV})$ & -1.9424 \\
\hline Ionization potential & 6.3324 \\
\hline Electron affinity & 1.9424 \\
\hline Energy gap (eV) & 4.3900 \\
\hline Electronegativity & 4.1374 \\
\hline Chemical potential & -4.1374 \\
\hline Chemical hardness & 2.1950 \\
\hline Chemical softness & 0.2278 \\
\hline Electrophilicity index & 3.8993 \\
\hline
\end{tabular}

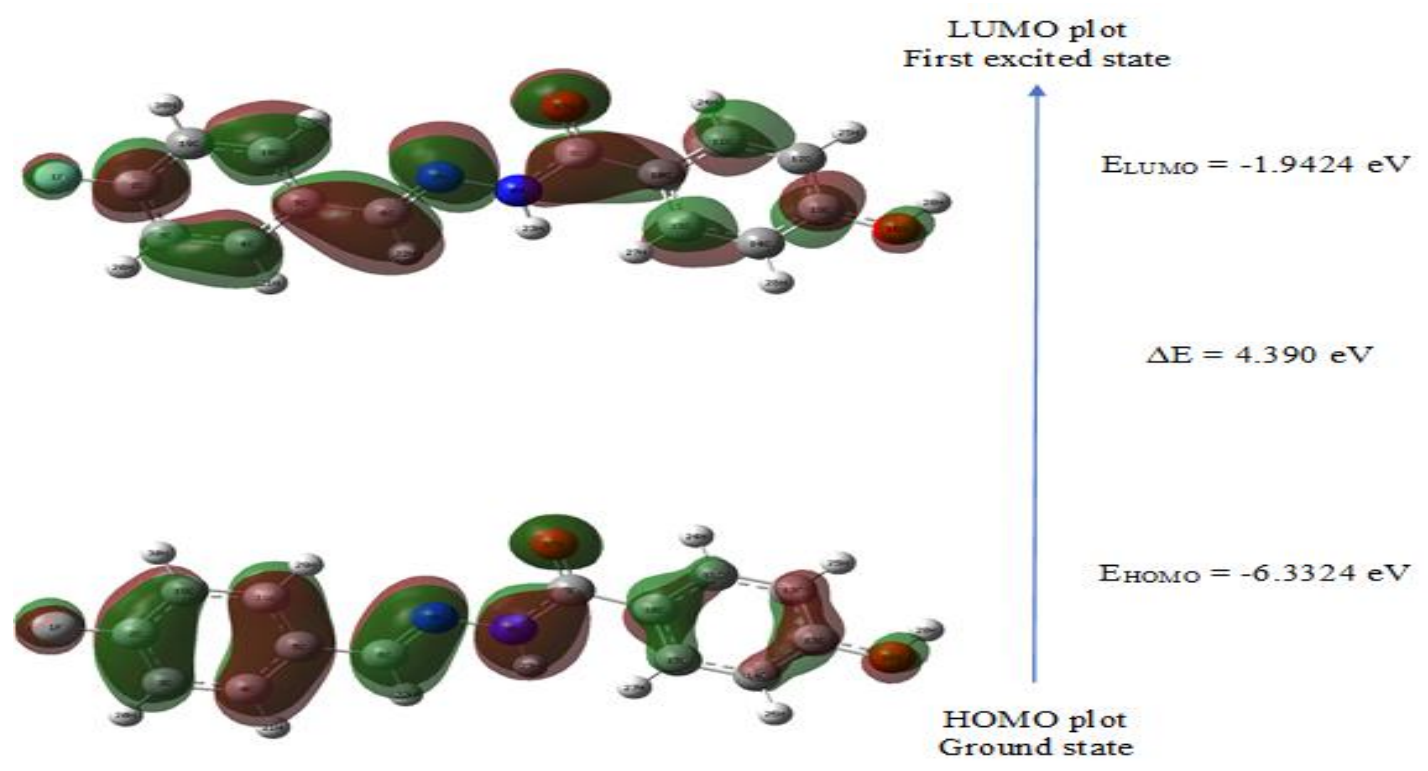

Figure 2. HOMO-LUMO energy values with surface of title compound 


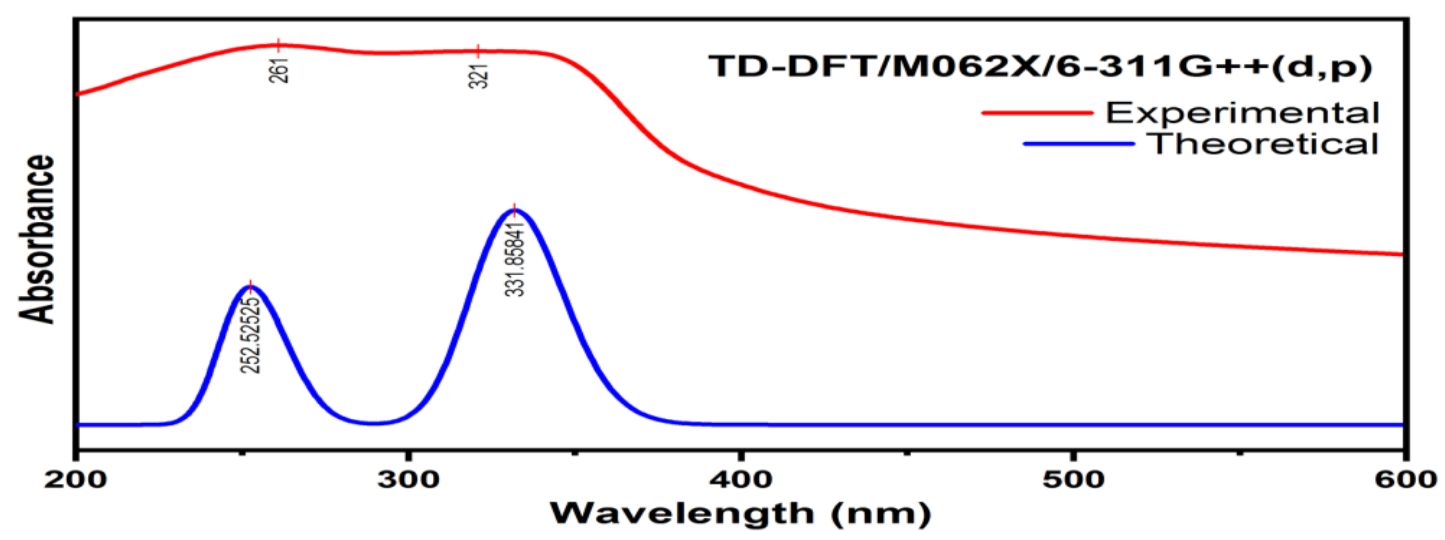

Figure 3. Recorded and computed UV-Vis comparison spectra of title compound

Table 3. Theoretically calculated values of title compound by TD-DFT procedure

\begin{tabular}{|c|c|c|c|c|c|}
\hline No. & Energy $\left(\mathbf{c m}^{-\mathbf{1}}\right)$ & $\begin{array}{c}\text { Wavelength } \\
(\mathbf{n m})\end{array}$ & $\begin{array}{c}\text { Osc. } \\
\text { Strength }\end{array}$ & Symmetry & Major contribs \\
\hline 1 & 30141.74 & 331.7658 & 0.2317 & Singlet-A & HOMO->LUMO (77\%) \\
\hline 2 & 38429.09 & 260.2195 & 0.0624 & Singlet-A & $\begin{array}{c}\text { H-5->LUMO (24\%), H-5->L+1 (15\%), H-4- } \\
\text { >LUMO (32\%) }\end{array}$ \\
\hline 3 & 40083.33 & 249.4802 & 0.1161 & Singlet-A & $\begin{array}{c}\text { H-6->LUMO (12\%), H-3->LUMO (26\%), } \\
\text { HOMO->L+3 (14\%) }\end{array}$ \\
\hline
\end{tabular}

\section{Molecular Electrostatic Potential}

MEP explores molecular shape, molecular size, and chemical reactivity by color grading [17]. The generated MEP map of FBFBH compound is shown in Figure 4. From the map, red colour reveals maximum negative electrostatic potential, blue colour shows maximum positive electrostatic potential whereas green indicates zero potential in the headline compound and the MEP surface is mapped in the range of $-7.068 \times 10^{-2} \mathrm{eV}$ to $7.068 \times 10^{-2} \mathrm{eV}$. From the results, maximum negative potential is on the carbonyl group which is indicated in red colour.

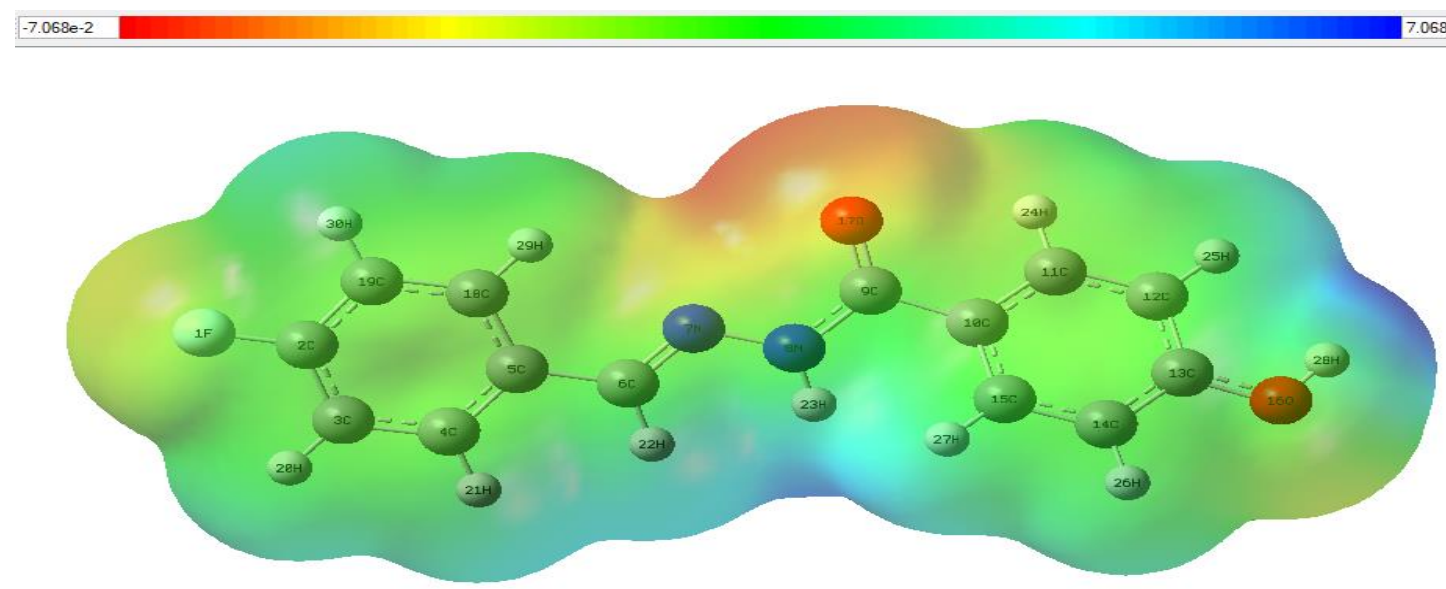

Figure 4. Molecular electrostatic potential surface of title compound 


\section{Dual Descriptor Analysis}

Reactive sites of chemical structure can be analyzed from mulliken charges by calculating Fukui functions and dual descriptors $[18,19]$. For the title compound, the negative $\Delta \mathrm{f}$ values are -0.02337 , $0.02597,-0.06915,-0.04507,-0.00027,-0.00758,-0.02744,-0.0008,-0.02956,-0.03294,-0.01088,-$ $0.00866,-0.00198,-0.01984,-0.00255$ and the corresponding atoms of these values are C6, N7, C9, $\mathrm{C} 11, \mathrm{C} 12, \mathrm{C} 13, \mathrm{C} 14, \mathrm{C} 15, \mathrm{O} 17, \mathrm{C} 18, \mathrm{H} 24, \mathrm{H} 25, \mathrm{H} 27, \mathrm{H} 28$ and H30, respectively. These observed results reveal that $\mathrm{O} 17=\mathrm{C} 9$ atoms with -0.02956 is under electrophilic attack.

\section{Drug Likeness}

For the present study, various rules are implemented on the FBFBH compound to find if the compound violates any rule and results are studied [20]. The CMC like rule is qualified and has zero violations, Lead like rule is satisfactory, if binding affinity value is greater than0.1microM. MDDR like rule has mid structure range since there are no rings whereas the crucial Rule of Five (ROF) is satisfactory and there are no violations. WDI like rule comes under $90 \%$ cutoff and not violated. From these results, it shows FBFBH compound has adequate drug likeness properties, and it is desirable for drug discovery process.

\section{ADME}

ADME properties have vital role in drug development process, these parameters are studied for the FBFBH compound [21]. Blood brain barrier (BBB) permeability is 0.880911 , Buffer solubility value is 34.3988, Caco2 value is 18.5044 and it is CYP 2C19, CYP 2C9 inhibitor. The HIA value is 92.24715, MDCK is 2.18067, PPB (Plasma protein binding) is 80.956947, Pure water solubility is 52.0311, Skin permeability is $-3.51581, \mathrm{SK} \log \mathrm{D}$ and $\mathrm{SK} \log \mathrm{P}$ value is 2.88487 , SKlogS buffer is -3.8755 . These obtained values fall under the limit and has an essential role in pharmaceutical development.

\section{Toxicity}

Concentration of drug can be identified from the toxic parameters [22]. For FBFBH compound, algae at value are 0.0546867 and Ames test is mutagen whereas hERG inhibition is at medium risk range. The important parameters like Carcino mouse is negative and dalphiaat, medakaat, minnow at parameters values are $0.130129,0.026422$ and 0.0174972 , respectively. TA10010RLI value is positive, TA100NA is negative, TA1535 10RLI is negative, TA1535NA is negative. Overall these values show the intoxic nature of the headline compound.

\section{Ramachandran Plot}

Ramachandran plot is used to determine the torsional angles that are allowed and gives insight into the peptide structures [23].It unveils the phi-psi torsion angles for every residue in the chosen proteins namely 1 R6A and 5OP9 which is shown in figure 5 and 6 . From the figures, it can be observed that most of the amino acids are present in the darkest region illustrated here as red and only few are 
spotted in the disallowed regions. This validates that the selected proteins are highly stable in nature and can be used to study protein ligand interactions.

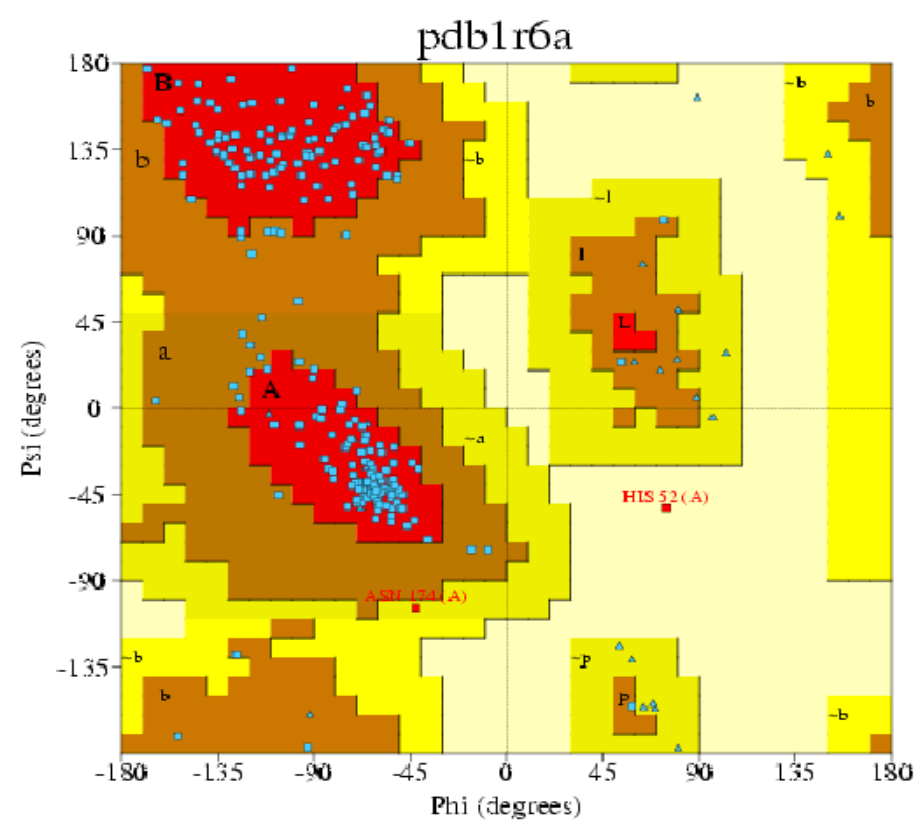

Figure 5. Ramachandran plot for 1R6A protein

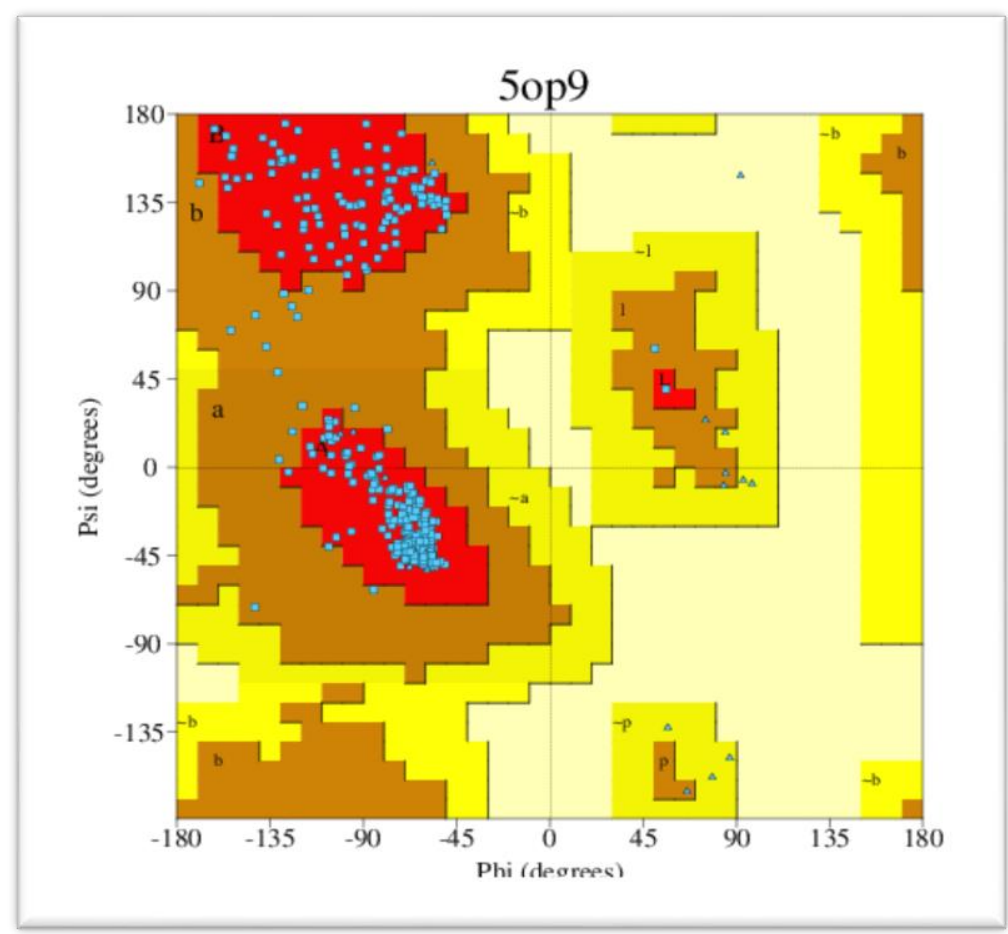

Figure 6. Ramachandran plot for $5 \mathrm{OP} 9$ protein 


\section{Molecular Docking}

Molecular docking is very important in structural molecular biology, pharmacogenomics, and computer-assisted drug development. Binding energy can be calculated from docking processes. Molecular docking experiments assist us in determining the precise binding position of the protein and ligand [24, 25]. Docking study aids in finding the protein ligand binding interactions and also it reduce the cost and time in drug designing process and it is done using Autodock Tools [26-28]. Anti microbial activites, antimycobacterial tuberculosis and binding affinity were studied for receptor 5OP9. Twenty cytochrome P450 enzymes are encoded by Mycobacterium tuberculosis (CYPs or P450s). CYP121A1 is one of these, and it has been shown that it is needed for microbial viability. RMSD gradient for naturally occurred compounds were explained in previous studies [29]. In the current docking study, binding location of the chosen ligand and the proteins are investigated. Target proteins are 1R6A viral protein and 5OP9 mycobacterial protein are obtained from PDB. Chosen protein crystal structures were prepared using PYMOL interface. To obtain the optimized structure of the FBFBH ligand, it is docked into the active sites of the 1R6A, 5OP9 and 100 docking runs are executed to find the best fit binding sites with lowest binding energy. The estimated inhibition constants and binding energy values of PL interactions with 5OP9 and 1R6A receptor proteins are 29.68, $117.7 \mu$ mand -6.18, -5.36 kcal/mol, respectively. The bonded residues, RMSD values are shown in Table 4. The binding orientations of 1R6A, 5OP9 proteins and FBFBH ligand are shown in Figure 7 and 8.

In this present work, we investigated the structural properties of FBFBH compound. The significant bondsin the FBFBH compound are N7-N8, N8-H23, C9=O17, O16-H28, F1-C2 and the corresponding bond length values are $1.355,1.016,1.214,0.963,1.354 \dot{\mathrm{A}}$. From UV-vis spectral analysis, absorption maxima of observed and calculated values are 261 and $321 \mathrm{~nm}$. The FMO study supplied the theoretical justification for considering the chosen compound to be biologically active and the band gap energy of FBFBH compound is found to be $4.39 \mathrm{eV}$. The reactive sites present in the compound are revealed from Dual descriptor analysis and $\mathrm{O} 17=\mathrm{C} 9$ atoms with -0.02956 is under electrophilic attack. Drug likeness, ADME and Toxicity studies validates that FBFBH compound is suitable for drug development process. Quantitative evaluation of 5OP9, 1R6A proteins is studied using Ramachandran plot, which shows the chosen proteins are structurally stable. The computed minimum binding energy values of ligand - 1R6A, 5OP9 the receptors proteins are -6.18 and $-5.36 \mathrm{kcal} / \mathrm{mol}$, respectively. Hence, this compound is predicted as a potential drug for bacterial disease and due to the formation of two hydrogen bond interactions with title compound, it might also be a drug candidate for viral (dengue) disease. 
Table 4. H Bond interactions of FBFBH ligand with 1R6A and 5OP9 receptor proteins

\begin{tabular}{|c|c|c|c|c|c|c|}
\hline Protein (PDB-ID) & $\begin{array}{l}\text { Bonded } \\
\text { residue } \\
\quad \mathrm{s}\end{array}$ & $\begin{array}{c}\text { Bond } \\
\text { distance } \\
(\AA)\end{array}$ & $\begin{array}{c}\text { Estimate } \\
\mathbf{d} \\
\text { Inhibitio } \\
\mathrm{n} \\
\text { constant } \\
(\mu \mathrm{m}) \\
\end{array}$ & $\begin{array}{c}\text { Binding } \\
\text { energy } \\
\text { (kcal/mol } \\
\text { ) }\end{array}$ & $\begin{array}{c}\text { Intermolecula } \\
\text { r energy } \\
(\mathbf{k c a l} / \mathbf{m o l})\end{array}$ & $\begin{array}{l}\text { Reference } \\
\text { RMSD }\end{array}$ \\
\hline \multirow{5}{*}{$\begin{array}{c}5 \mathrm{OP} 9 \\
\text { (Anti bacterial protein) }\end{array}$} & $\begin{array}{c}\text { ASN } \\
74 / \\
\text { UNL } \\
1{ }^{\prime} \mathrm{H} \\
\end{array}$ & 2.3 & \multirow{5}{*}{29.68} & \multirow{5}{*}{-6.18} & \multirow{5}{*}{-7.37} & \multirow{5}{*}{267.821} \\
\hline & $\begin{array}{l}\text { ARG } \\
72 / \\
\end{array}$ & \multirow{2}{*}{2.8} & & & & \\
\hline & $\begin{array}{l}\text { UNL } \\
1^{\prime} \mathrm{O}\end{array}$ & & & & & \\
\hline & $\begin{array}{c}\text { VAL } \\
78 / \\
\text { UNL } \\
1{ }^{\prime} \mathrm{O} \\
\end{array}$ & 2.8 & & & & \\
\hline & $\begin{array}{c}\text { THR } \\
77 / \\
\text { UNL } \\
1 \text { 'O }\end{array}$ & 2 & & & & \\
\hline \multirow{2}{*}{$\begin{array}{c}\text { 1R6A } \\
\text { (Antiviral protein) }\end{array}$} & $\begin{array}{l}\text { VAL } \\
130 \\
\end{array}$ & 1.9 & \multirow{2}{*}{117.7} & \multirow{2}{*}{-5.36} & \multirow{2}{*}{-6.55} & \multirow{2}{*}{43.01} \\
\hline & $\begin{array}{l}\text { VAL } \\
132\end{array}$ & 2 & & & & \\
\hline
\end{tabular}

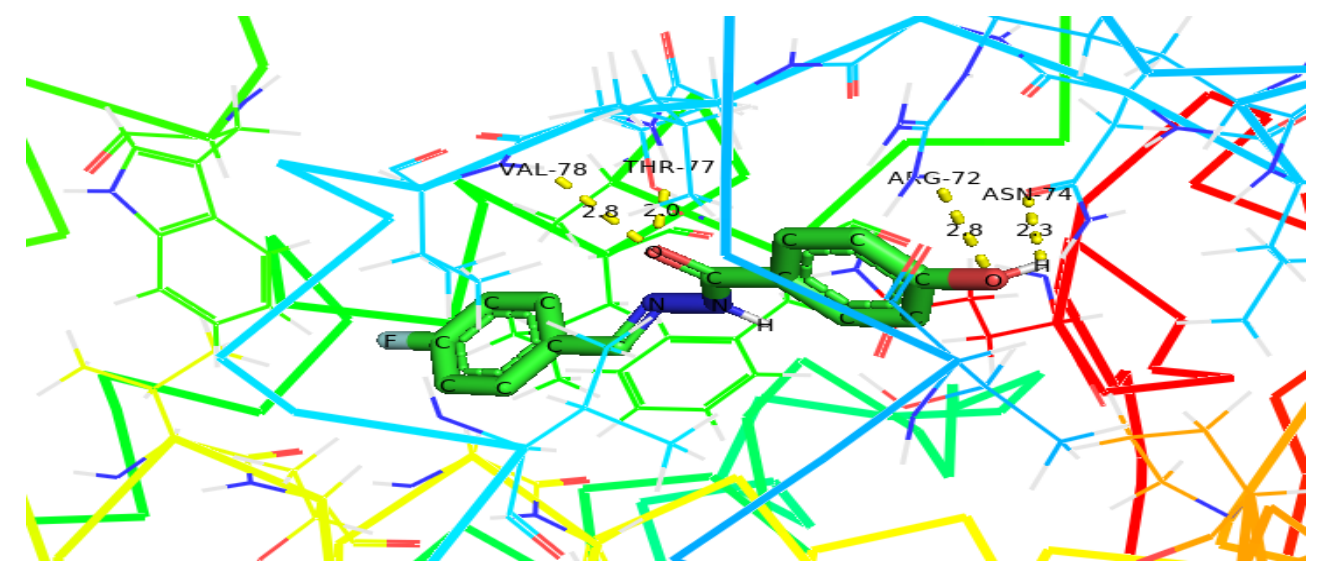

Figure 7. H-Bond interaction of 5OP9 protein with FBFBH ligand

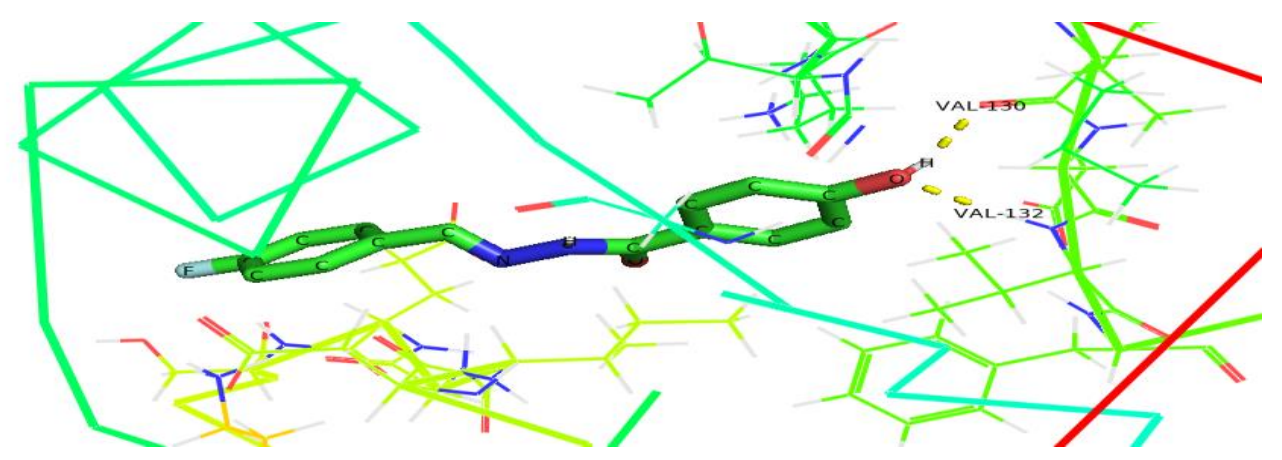

Figure 8. H-Bond interaction of 1R6A protein with FBFBH ligand 


\section{AUTHOR CONTRIBUTIONS}

Conception: A.K.V., F.B.A.; Design: A.K.V., S.M., F.B.A.; Supervision: H.R., S.M., B.N.; Resources: H.R.; S.M., B.N.; Materials: A.K.V., F.B.A.; Data collection and/or processing: A.K.V., F.B.A.; Analysis and/or interpretation: H.R., S.M., B.N.; Literature search: A.K.V., F.B.A.; Writing manuscript: A.K.V., F.B.A.; Critical review: H.R., S.M., B.N.; Other (Figures): A.K.V., F.B.A.

\section{CONFLICT OF INTEREST}

The authors declare no conflict of interest.

\section{REFERENCES}

1. Asif, F.B., Khan, F.L.A., Muthu, S., Raja, M. (2021). Computational evaluation on molecular structure (Monomer, Dimer), RDG, ELF, electronic (HOMO-LUMO, MEP) properties, and spectroscopic profiling of 8-Quinolinesulfonamide with molecular docking studies. Computational and Theoretical Chemistry, 1198, 113169. [CrossRef]

2. Nisa, S., Yusuf, M. (2020). Synthesis and antimicrobial evaluation of varied ring new heterocycles. Indian Journal of Chemistry -Section $B \quad(I J C-B), \quad 59 B, \quad 420-430$, from http://nopr.niscair.res.in/bitstream/123456789/54148/1/IJCB\%2059B\%283\%29\%20420-430.pdf

3. Rahuman, M.H., Muthu, S., Raajaraman, B.R., Raja, M. (2020). Quantum computational, spectroscopic and molecular docking investigations on 4-Acetylamino-benzoic acid methyl ester: A prospective anticancer drug. Chemical Data Collections, 26, 100352. [CrossRef]

4. Manikandan, V., Vanangamudi, G., Arulkumaran, R., Christuraj, P., Thirunarayanan, G. (2020). Antimicrobial potent (E)-2-(1-phenylethylidene)-1-tosylhydrazines. Indian Journal of Chemistry Section $\quad B \quad$ (IJC-B), 59B, 399-405, from http://nopr.niscair.res.in/bitstream/123456789/54150/1/IJCB\%2059B\%283\%29\%20399-405.pdf

5. Joshi, R., Sharma, J., Pardasani, R.T. (2017). Synthesis, characterization and antimicrobial activity of some 2,4-dibromo-1,5-dimorpholino/dipiperidino-pentane-3-ones. Indian Journal of Chemistry $\begin{array}{lllll}\text { Section } & B & (I J C-B), & 56 \mathrm{~B}, & 183-191,\end{array}$ http://nopr.niscair.res.in/bitstream/123456789/40520/1/IJCB\%2056B(2)\%20183-191.pdf

6. Priya, B., Kumar, A., Sharma, N. (2020). Synthesis, characterization, and biological properties of oxidovanadium(IV) complexes of acetylsalicylhydroxamic acid (N-acetyloxy-2-hydroxybenzamide) as potential antimicrobials. Journal of Chemical Research, 44(7-8), 460-470. [CrossRef]

7. Ienascu, I.M.C., Balaes, T., Petre, C.V., Pop, R.O., Cata, A., Stefanut, M.N., Albu, P., Poenaru, M. (2018). Novel n-(2-bromo-phenyl)-2-hydroxy-benzamide derivatives with antifugal activity. Revista de Chimie, 69(7), 1876-1880. [CrossRef]

8. Garg, B.S., Bhojak, N., Bist, J.S., Singh, B.K. (1999). Micellar spectrofluorimetric determination of zinc (II) with $\mathrm{N}$-(2'- pyridyl)-2-hydroxybenzamide. Indian Journal of Chemistry - Section A Inorganic, Physical, Theoretical and Analytical Chemistry, 38(4), 392-394. Retrieved from http://nopr.niscair.res.in/bitstream/123456789/15664/1/IJCA\%2038A\%284\%29\%20392-394.pdf 
9. Furia, E. (2017). Study of complexation equilibria between the iron(III) ion and 2-hydroxybenzamide in aqueous solution. Journal of Solution Chemistry, 46(8), 1596-1604. [CrossRef]

10.Thamarai, A., Vadamalar, R., Raja, M., Muthu, S., Narayana, B., Ramesh, P., Sevvanthi, S., Aayisha, S. (2020). Molecular structure conformational analyses, solvent-electronic studies through theoretical studies and biological profiling of (2E)-1-(3-bromo-2-thienyl)-3-(4-chlorophenyl)-prop2-en-1-one. Journal of Molecular Structure, 1202, 127349. [CrossRef]

11.M.J. Frisch, G.W. Trucks, H.B.S. (Revision A.02). Gaussian 09, Gaussian, Inc., Wallingford CT, 2016.

12.The PyMOL Molecular Graphics System,Version 1.8. (2015). The PyMOL Molecular Graphics System, Version 1.8,Schrodinger LLC.

13.Hansen, L.K., Perlovich, G.L., Bauer-Brandl, A. (2007). 4-Hydroxybenzamide. Acta CrystallographicaSection E: Structure Reports Online, 63(5). [CrossRef]

14.Kuruvilla, T.K., Muthu, S., Prasana, J.C., George, J., Sevvanthi, S. (2019). Spectroscopic (FT-IR, FT-Raman), quantum mechanical and docking studies on methyl[(3S)-3-(naphthalen-1-yloxy)-3(thiophen-2-yl)propyl]amine. Jouranl of Molecular Structure, 1175, 163-174. [CrossRef]

15.Pandey, M., Muthu, S., Nanje Gowda, N.M. (2017). Quantum mechanical and spectroscopic (FT-IR, FT-Raman,1H,13C NMR, UV-Vis) studies, NBO, NLO, HOMO, LUMO and Fukui function analysis of 5-Methoxy-1H-benzo[d]imidazole-2(3H)-thione by DFT studies. Journal of Molecular Structure, 1130, 511-521. [CrossRef]

16.Fathima Rizwana, B., Prasana, J.C., Muthu, S., Abraham, C.S. (2019). Molecular docking studies, charge transfer excitation and wave function analyses (ESP, ELF, LOL) on valacyclovir: A potential antiviral drug. Computational Biology and Chemistry, 78, 9-17. [CrossRef]

17.Aayisha, S., Renuga Devi, T.S., Janani, S., Muthu, S., Raja, M., Hemamalini, R. (2019). Structural (PES), AIM, spectroscopic profiling (FT-IR, FT-Raman, NMR and UV), HOMO-LUMO and docking studies of 2,2-dimethyl-N-(2-pyridinyl)propanamide - a DFT approach. Chemical Data Collections, 24, 100287. [CrossRef]

18.Jardínez, C., Vela, A., Cruz-Borbolla, J., Alvarez-Mendez, R.J., Alvarado-Rodríguez, J.G. (2016). Reduced density gradient as a novel approach for estimating QSAR descriptors, and its application to 1, 4-dihydropyridine derivatives with potential antihypertensive effects. Journal of Molecular Modeling, 22, 296. [CrossRef]

19.Asif, F.B., Khan, F.L.A., Muthu, S., Raja, M. (2020). Elaborated molecular structure, molecular docking and vibrational spectroscopic investigation of $\mathrm{N}$-((4-aminophenyl)sulfonyl)benzamide with Density functional theory. Chemical Data Collections, 31, 100609. [CrossRef]

20.Arulaabaranam, K., Mani, G., Muthu, S. (2020). Computational assessment on wave function (ELF, LOL) analysis, molecular confirmation and molecular docking explores on 2-(5-Amino-2Methylanilino)-4-(3-pyridyl) pyrimidine. Chemical Data Collections, 29, 100525. [CrossRef]

21.Vijayakumar, V., Prabakaran, A., Radhakrishnan, N., Muthu, S., Rameshkumar, C., Isac Paulraj, E. (2019). Synthesis, characterization, spectroscopic studies, DFT and molecular docking analysis of N4, N4'-dibutyl-3,3'-diaminobenzidine. Journal of Molecular Structure, 1179, 325-335. [CrossRef] 
22.Psimadas, D., Georgoulias, P., Valotassiou, V., Loudos, G. (2012). Molecular Nanomedicine Towards Cancer: Journal of Pharmaceutical Sciences, 101(7), 2271-2280. [CrossRef]

23.Manjusha, P., Prasana, J.C., Muthu, S., Rizwana, B.F. (2020). Spectroscopic elucidation (FT-IR, FTRaman and UV-visible) with NBO, NLO, ELF, LOL, drug likeness and molecular docking analysis on 1-(2-ethylsulfonylethyl)-2-methyl-5-nitro-imidazole: An antiprotozoal agent. Computational Biology and Chemistry, 88, 107330. [CrossRef]

24.Yilmaz, S., Ataei, S., Yildiz, I. (2020). Molecular docking studies on some benzamide derivatives as topoisomerase inhibitors. Ankara Üniversitesi Eczactlık Fakültesi Dergisi, 44, 470-480. [CrossRef]

25.Thomas, R., Hossain, M., Mary, Y.S., Resmi, K.S., Armaković, S., Armaković, S.J., Nanda, A.K., Ranjan, V.K., Vijayakumar, G., Van Alsenoy, C. (2018). Spectroscopic analysis and molecular docking of imidazole derivatives and investigation of its reactive properties by DFT and molecular dynamics simulations. Journal of Molecular Structure, 1158, 156-175. [CrossRef]

26.Haruna, K., Kumar, V.S., Sheena Mary, Y., Popoola, S.A., Thomas, R., Roxy, M.S., Al-Saadi, A.A. (2019). Conformational profile, vibrational assignments, NLO properties and molecular docking of biologically active herbicide1,1-dimethyl-3-phenylurea. Heliyon, 5(6), e01987. [CrossRef]

27.Al-Zaqri, N., Pooventhiran T., Alsalme A., Warad I., John A.M., Thomas R. (2020) Structural and physico-chemical evaluation of melatonin and its solution-state excited properties, with emphasis on its binding with novel coronavirus proteins, Journal of Molecular Liquids, 318, 114082. [CrossRef]

28.Pooventhiran, T., Bhattacharyya, U., Rao, D.J., Chandramohan, V., Karunakar, P., Irfan, A., Mary, Y.S., Thomas, R. (2020) Detailed spectra, electronic properties, qualitative non-covalent interaction analysis, solvatochromism, docking and molecular dynamics simulations in different solvent atmosphere of cenobamate, Structural Chemistry, 31, 2475-2485. [CrossRef]

29.Taban, I.M., Elshihawy, H., Torun, B., Zucchini, B., Williamson, C.J., Altuwairigi, D., Ngu, A., McLean, K.J., Levy, C.W., Sood, S., Marino, L.B., Munro, A.W., S. de Carvalho, L.P., Simons, C. (2017). Novel aryl substituted pyrazoles as small molecule inhibitors of cytochrome P450 CYP121A1: synthesis and antimycobacterial evaluation. Journal of Medicinal Chemistry, 60(24), 10257-10267. [CrossRef] 